\title{
POLA KOMUNIKASI GURU DI RUANG PUBLIK SEKOLAH
}

\author{
Dr. Adam Latuconsina ${ }^{1}$ \\ Dosen pada Program Studi PAI FITK IAIN Ambon ${ }^{1}$ \\ adamlatuconsina@iainambon.ac.id
}

\begin{abstract}
The communication of teachers in the public room is one of the strategies for transferring the lesson material to the participants. Done through forms of communication so that students are motivated to build dialogue and interaction as part of the learning process. The results of this research show that the teacher's community pattern in the school public room has been effectively and intensely: [1] Process of communication of teachers conducted through observations of behavioral students to know the ins and outs of psychology every learner. Then the teacher seeks to establish good communication with the aim of attracting sympathy. This is done because some learners who are less eager in the learning process, such as: not focused on learning, can not memorize in front of the class, and pay less attention to school assignments. [2] Teacher communication patterns used in learning are: personal and group communication patterns include; [a] Such verbal communication, delivering the material directly to the learners. [b] Non-verbal, such as: demonstrated behavior, neat dressing style, style of speech and the way of dialogue with teachers when delivering material. [3] Media such as: using books relating to the material being taught. With this teacher's communication pattern gives a positive impact on learners so that they can be motivated to follow the subject matter.
\end{abstract}

Keywords: teacher communication pattern, student motivation

Abstrak: Komunikasi guru di ruang publik sekolah merupakan salah satu strategi dalam mentransfer materi pelajaran kepada peserta didiknya. Dilakukan melalui bentuk-bentuk komunikasi sehingga siswa termotivasi untuk membangun dialog dan interaksi sebagai bagian dari proses pembelajaran. Hasil penelitian ini menunjukan pola komunkasi guru di ruang publik sekolah telah berlangsung secara efektif dan intens melalui: [1] proses komunikasi guru yang dilakukan melalui pengamatan prilaku peserta didik untuk mengetahui seluk beluk psikologi setiap peserta didik. Kemudian guru berusaha membangun komunikasi yang baik dengan tujuan menarik simpati. Hal ini dilakukan karena nampak beberapa peserta didik yang kurang bersemangat dalam proses pembelajaran, seperti: tidak fokus dalam belajar, tidak bisa menghafal di depan kelas, dan kurang memperhatikan tugas sekolah. [2] Pola komunikasi guru yang digunakan dalam pembelajaran yaitu: Pola komunikasi personal dan kelompok meliputi; [a] komunikasi verbal seperti, menyampaikan materi secara langsung kepada peserta didik. [b] nonverbal, seperti: menunjukkan perilaku, gaya berpakaian yang rapi, gaya bicara dan cara dialog dengan guru ketika memberikan materi. [3] komunikasi bermedia seperti: menggunakan buku-buku yang berhubungan dengan materi yang diajarkan. Dengan pola komunikasi guru ini memberikan dampak yang positif terhadap peserta didik sehingga mereka dapat termotivasi untuk mengikuti materi pelajaran.

Kata Kunci: Pola Komunikasi Guru, Motivasi Peserta Didik 


\section{PENDAHULUAN}

Komunikasi merupakan salah satu bentuk transmission of knowledge dalam proses pembelajaran, sifatnya mentransfer ilmu pengetahuan berupa materi pelajaran dari guru kepada peserta didik. Pola komunikasi dalam pembelajaran menjadi salah satu indikator keberhasilan belajar. Komunikasi guru tidak hanya dilakukan secara verbal saja tapi juga komunikasi nonverbal untuk meningkatkan pemahaman peserta didik terhadap informasi materi pembelajaran. Komunikasi guru di ruang publik sekolah dengan pola mengajak, membujuk, serta mengarahkan peserta didik untuk bersedia melakukan tindakan yang berkaitan dengan tujuan pembelajaran.

Perkembangan teknologi informasi saat ini, memberikan dampak terhadap pola pengajaran di sekolah, guru tidak lagi bertindak sebagai penyaji informasi tunggal, akan tetapi juga berperan sebagai fasilitator, motivator, dan pembimbing dalam memberikan kesempatan kepada peserta didik untuk mencari dan mengolah sendiri informasi (Hamza Uno, 2007). Guru memiliki kompetensi mengembangkan pembelajaran yang efektif seperti membangun sebuah rumah yang terdiri dari batu bata dan memiliki pondasi bangunan yang kokoh. Sama halnya dengan belajar, guru mampu menciptakan pembelajaran yang efektif, inovatif, kreatif, bahkan menyenangkan yang dirasakan oleh peserta didik, sehingga mereka merasa termotivasi dalam mengikuti materi pelajaran.

Salah satu teori komunikasi yang masih digunakan dalam dunia pendidikan yaitu teori Stimulus- Organism- Response (SOR), memberikan makna bahwa stimulus atau pesan yang disampaikan kepada komunikan mungkin diterima atau mungkin ditolak. Komunikasi akan berlangsung jika ada perhatian dari komunikan. Proses berikutnya komunikan mengerti. Kemampuan komunikan inilah yang melanjutkan proses berikutnya. Setelah komunikan mengolahnya dan menerimanya, maka terjadilah kesedian komunikan untuk mengubah sikap (Onong Uchjana Effendi, 1993). 
Teori tersebut diatas, memberikan gambaran bahwa komunikasi guru secara verbal maupun nonverbal kepada peserta didik akan diterima atau tidak bergantung cara guru berkomunikasi, sehingga bisa membuat peserta didik menangkap apa yang dikomunikasikan.

Guru dan peserta didik merupakan dua komponen yang dapat dianalogikan seperti teori simbiosis mutualisma, yaitu peran yang saling menguntungkan satu dengan yang lain. Jika salah satu komponen saja yang aktif tentunya tidak akan menghasilkan dampak yang maksimal sebagai timbal balik kemampuan komunikasi yang baik dari guru, peserta didik hendaknya juga memiliki kemampuan berkomunikasi yang baik kepada guru. Interaksi komunikatif seperti inilah yang akan memberikan dampak terhadap guru dan peserta didik. Guru yang profesional dapat mengkomunikasikan pengetahuan sehingga peserta didik dapat memahaminya. Keberhasilan pembelajaran sangat ditentukan oleh kompetensi guru dalam menyampaikan materi pelajaran melalui interaksi komunikasi terhadap pesan yang disampaikan kepada peserta didik (Wina Sanjaya, 2006).

Ruang publik sekolah merupakan arena perjumpaan antara guru, para staf administrasi, peserta didik maupun orang tua wali saling berkomunikasi yang dapat memeengaruhi semangat belajar peserta didik. Komunikasi yang dilakukan guru selalu menunjukan sikap dan perilaku yang simpatik dan memperlihatkan suritauladan yang baik, sehingga dapat merubah situasi dan kondisi di lingkungan sekolah sehingga dapat memotivasi siswa untuk belajar, misalnya rajin membaca dan berdiskusi, menjadi daya tarik dalam kegiatan belajar peserta didik (Muhibin Syah, 1995).

Peserta didik termotivasi untuk melaksanakan semua kegiatan belajar dengan sungguh-sungguh dan penuh gairah. Sebaliknya, peserta didik yang belajar dengan motivasi rendah, akan memengaruhi aktivitas peserta didik dalam mengerjakan tugas-tugas yang berhubungan dengan pelajaran. Motivasi belajar peserta didik di MTs Negeri Batu Merah Ambon masih sangat 
rendah. Hasil observasi yang dilakukan penulis dalam proses pembelajaran berlangsung, masih terdapat sebagian peserta didik sering bercakap-cakap dengan teman, dan bermain handphone, bahkan juga ada yang menundukan kepala di atas meja saat pembelajaran berlangsung, kurangnya komunikasi yang efektif antara guru dan peserta didik dalam mengembangkan motivasi belajar peserta didik. Dengan demikian, motivasi tidak hanya timbul dan dipengaruhi dari peserta didik sendiri, tetapi juga dipengaruhi oleh komunikasi guru dalam kelas maupun di lingkungan sekolah.

\section{METODE}

Penelitian ini mengambil setting lakosi pada MTs Negeri Batu Merah Ambon, dengan pendekatan deskriptif kualitatif. Penelitian dilakukan melalui; [1] Observasi: peneliti mengamati langsung lokasi penelitian untuk proses pengumpulan data yang dilakukan untuk mengetahui pola komunikasi guru terhadap peningkatan motivasi belajar peserta didik serta membaur bersama guru sebagai subjek penelitian, [2] melakukan wawancara dengan sejumlah guru yang berada di MTs Negeri Batu Merah Ambon melalui Tanya jawab dan sharing pendapat dalam rangka mengetahui masalah yang dihadapi terkait dengan tema yang dikaji, [3] Dokumentasi adalah sekumpulan berkas yakni mencari data mengenai hal-hal berupa catatan, transkrip, buku, surat kabar, majalah, prasasti, notulen, agenda dan sebagainya.

Teknik analisis data merupakan upaya mencari dan menata secara sistematis catatan, hasil observasi, wawancara dan lainnya untuk meningkatkan pemahaman tentang kasus yang diteliti dan menyajikan sebagai temuan bagi orang lain. Teknik analisis data adalah proses mengorganisasikan dan mengurutkan data dalam pola, kategori dan satuan uraian dasar sehingga dapat ditemukan. Teknik analisis data yang digunakan adalah metode deskriptif. Analisis data dilakukan saat peneliti berada di lapangan dengan cara mendeskripsikan segala data yang telah didapat, lalu dianalisis sedemikian rupa secara sistematis, cermat dan akurat (Mohammad Ali, 1993). Dilakukan 
melalui: [1] Reduksi data adalah proses memilih, menyederhanakan, memfokuskan, mengabstrasikan dan mengubah data kasar yang muncul dari catatan-catatan lapangan (Mohammad Ali, 1993). [2] Sajian data (display data) adalah suatu cara merangkai data dalam suatu organisasi yang memudahkan untuk membuat kesimpulan dan atau tindakan yang diusulkan. [3] Verifikasi data atau menyimpulkan data yaitu penjelasan tentang makna data dalam suatu konfigurasi yang secara jelas menunjukkan alur kausalnya, sehingga dapat diajukan proposisi-proposisi yang terkait dengannya. Pada bagian akhir ini, akan muncul kesimpulan-kesimpulan yang mendalam secara komprehensif dari data.

\section{HASIL}

Komunikasi memegang peranan penting dalam keberhasilan interaksi yang terjadi.Mengelola kelas dan memecahkan konflik dalam pembelajaran, secara konstruktif membutuhkan keterampilan komunikasi yang baik.Terdapat tiga aspek utama komunikasi dalam pembelajaran, yaitu keterampilan berbicara, mendengar dan komunikasi non verbal. Saat berbicara dihadapan kelas dan peserta didik, guru dapat mengkomunikasikan informasi secara jelas. Pola komunikasi merupakan unsur yang sangat penting agar pembelajaran yang dilakukan oleh guru dan proses belajar yang diikuti peserta didik dapat berjalan dengan baik (Juliana Ulfa, 2016). Saat berkomunikasi dengan peserta didik, guru diharapkan menggunakan tata bahasa yang benar, kosa kata yang dapat dipahami dan tepat pada perkembangan anak, melakukan penekanan pada kata-kata kunci dengan mengulang penjelasan, berbicara dengan tempo yang tepat, tidak menyampaikan hal-hal yang kabur atau bermakna ganda (ambigu), serta menggunakan perencanaan dan pemikiran logis sebagai dasar berbicara (Juliana Ulfa, 2016).

Guru didalam kegiatan belajar dan pembelajaran, sesungguhnya ia sedang melaksanakan kegiatan komunikasi. Untuk itu guru harus memilih dan menggunakan kata-kata yang berada dalam jangkauan atau medan 
pengalaman peserta didiknya, agar dapat dimengerti dengan baik oleh mereka sehingga pesan pembelajaran yang disampaikan dapat diterima oleh peserta didik dengan baik. Hal ini telah dilakukan oleh guru di MTs Negeri Batu Merah Ambon yaitu, dengan melakukan komunikasi verbal, non verbal, dan bermedia. Ini dilakukan, guna menciptakan iklim komunikatif dan dapat meningkatkan motivasi belajar peserta didik.

Pola komunikasi guru dengan peserta didik di dalam kelas dengan menggunakan lambang (Symbol) sebagai media atau saluran yang membantu peserta didik dalam menerima pembelajaran yang biasa disebut dengan komunikasi verbal, nonverbal dan bermedia. Selain itu, proses penyampaian pesan dari guru kepada peserta didik dengan menggunakan alat atau sarana sebagai media kedua setelah memakai lambang sebagai media pertama.

Sesuai dengan hasil kajian bahwa komunikasi guru dengan peserta didik MTs Negeri Batu Merah Ambon yang terjadi adalah komunikasi yang terkait dengan proses pembelajaran, komunikasi efektif dalam pembelajaran harus didukung dengan keterampilan komunikasi antar pribadi yang harus dimiliki oleh seorang guru. Komunikasi yang dilakukan guru untuk menangani peserta didik yang kurang aktif dalam mengikuti pembelajaran, di mana guru melakukan pendekatan dengan peserta didik, karena peserta didik mempunyai karakteristik yang unik seperti; memiliki kemampuan yang berbeda, minat yang berbeda, memerlukan kebebasan, memilih yang sesuai dengan dirinya dan merupakan pribadi yang aktif, Untuk itulah kemampuan berkomunikasi guru dalam kegiatan pembelajaran sangat diperlukan guna meningkatkan motivasi dan prestasi belajar peserta didik. Hal demikian dihadapi para guru di dalam kelas, dimana masih ada peserta didik yang kurang perhatian dan tidak tertib disaat proses pembelajaran berlangsung. Namun guru berusaha untuk memperhatikan peserta didik yang kurang perhatian dan tidak tertib, selanjutnya guru memberikan hukuman kepada peserta didik tersebut, dengan cara memberikan teguran dengan kata-kata yang mendidik, atau peserta didik 
di suruh menghafal di depan kelas, dan ternyata hal ini mampu memotivasi peserta didik.

Hal ini didukung dengan pendapat yang dikemukakan oleh, Brophy: bahwa terdapat lima faktor yang dapat mempengaruhi motivasi peserta didik yaitu: 1) harapan guru. 2) intruksi langsung. 3) umpan balik, 4) penguatan dan hadiah. 5) hukuman.

Guru memiliki peran yang sangat penting dalam pembelajaran. Untuk menjadi guru yang efektif, maka guru harus bisa menjadi yang terbaik dan mampu memecahkan konflik dalam pembelajaran. Dalam mengelola dan menciptkan ketertiban dalam kelas, guru membutuhkan keterampilan komunikasi yang baik. Sehingga alur komunikasi yang dibangun oleh guru melalui penyampain informasi, gerakan tubuh, atau Pola media lain yang digunakan guru untuk menarik perhatian dan mudah dipahami oleh peserta didik.

Guru yang terampil dapat menduga atau menyimpulkan dengan tepat bagian apa yang bisa dilihat dan didengar oleh peserta didiknya dan cara peserta didik belajar. Hal ini, menunjukkan bahwa aktifitas guru seperti mengatur suasana kelas, menyediakan tugas-tugas pada peserta didik dan memeriksanya, dan membangun gambaran otak membuat pengajaran terus menerus tak pernah merasa sempurna. Guru yang kreatif dan memiliki semangat untuk mencoba berbagai pendekatan pembelajaran baru, akan dengan senang hati menerapkan berbagai model pembelajaran. Keterampilan mengajar guru akan semakin baik, jika guru terus berlatih, memiliki kesungguhan, melakukan refleksi, dan mau belajar dari pengalaman.

Pola komunikasi efektif, yang digunakan dalam kegiatan pembelajaran adalah Pola komunikasi antarpersonal, dan komunikasi kelompok, misalnya komunikasi verbal yang dilakukan oleh guru mata pelajaran, berupa penyampaian materi. Non verbal diaplikasikan dengan perilaku dan cara berpakaian yang rapi yang dipakai ketika berada di dalam kelas, kemudian 
diikuti perlahan-lahan oleh peserta didik. Sedangkan untuk bermedia, hanya menggunakan buku sebagai media pembelajaran yang terkait dengan materi pelajaran. Berdasasrkan hasil pengamatan yang dilakukan peneliti, kedua proses tersebut dapat menghasilkan feed back (timbal balik) yang dimana dapat mengetahui apakah komunikasi dapat diterima dengan baik atau tidak. Selain itu, kedua proses tersebut dapat memaksimalkan penyampaian informasi dari guru kepada peserta didik. Agar informasi yang diberikan oleh guru dapat diterima dan dicerna dengan baik oleh peserta didik. Hal ini dapat dibuktikan dengan adanya beberapa peserta didik yang berani bertanya, bahkan ada juga peserta didik yang mampu menjawab pertanyaan temannya ketika pembelajaran berlangsung, walaupun dengan bahasa Indonesia yang terkadang masih dicampur dengan bahasa daerah. Namun dengan keadaan tersebut penulis sangat setuju dengan apa yang dilakukan oleh guru mata pelajaran dalam meningkatkan motivasi belajar peserta didik. Hal lain membuktikan bahwa peserta didik termotivasi dengan pembelajaran yaitu: tanggung jawab dalam mengerjakan tugas, baik tugas menghafal, individu maupun tugas kelompok, serta semangat dalam mengikuti pelajaran.

Pernyataan di atas didukung dengan pendapat Brophy: bahwa, motivasi belajar lebih mengutamakan respon kognitif, yaitu kecenderungan peserta didik untuk mencapai aktivitas akademis yang bermakna dan bermanfaat serta mencoba untuk mendapatkan keuntungan dari aktivitas tersebut. Peserta didik yang memiliki motivasi belajar akan memperhatikan pelajaran yang disampaikan, membaca materi sehingga bisa memahaminya, dan menggunakan strategi-strategi belajar tertentu yang mendukung (J. Brophy, 2004). Selain itu, peserta didik juga memiliki keterlibatan yang intens dalam aktivitas belajar tersebut, rasa ingin tahu yang tinggi, mencari bahan-bahan yang berkaitan untuk memahami suatu topik, dan menyelesaikan tugas yang diberikan. Peserta didik yang memiliki motivasi belajar akan bergantung pada apakah aktivitas tersebut memiliki isi yang menarik atau proses yang 
menyenangkan. Intinya, motivasi belajar melibatkan tujuan-tujuan belajar dan strategi yang berkaitan dalam mencapai tujuan belajar tersebut.

\section{PEMBAHASAN}

\section{Pola Komunikasi Guru di Ruang Publik Sekolah Bentuk-Bentuk Komunikasi Guru}

Pola komunikasi guru di ruang kelas merupakan magnet yang akan memberikan kontribusi yang sangat besar dalam mencapai tujuan pembelajaran. Beberapa teori komunikasi yang sering digunakan dalam pendidikan sebagaimana dikemukakan oleh Onong Uchjana Effendi bahwa pola komunikasi dibedakan dalam beberapa bentuk sebagai berikut :

1. Komunikasi personal ( Personal Communication) Komunikasi personal merupakan komunikasi yang dilakukan secara langsung seperti tatap muka atau melalui televisi kepada sejumlah orang secara serentak. Komunikasi personal dibagi menjadi dua yaitu : [a] komunikasi intrapersonal(intrapersonal communication) Komunikasi yang tampak pada kejadian berfikir, mengingat dan mengindra, [b] komunikasi antar personal yaitu bentuk komunikasi yang berproses adanya ide atau gagasan informasi seseorang kepada orang lain (Pawit M. yusuf, 1990).

2. Komunikasi kelompok Komunikasi kelompok merupakan komunikasi yang dilakukan dengan beberapa orang dengan saling tatap muka, dan adanya umpan balik dari komunkator (Onong Uchjana Effendy, 2001). Komunikasi kelompok dibagi menjadi dua bentuk yaitu :

a) Komunikasi kelompok kecil (smallgroupcommunication). Yaitu komunikasi yang dilakukan pada tempat tertentu atau ruangan dan hanya diikuti oleh beberapa orang. Misalnya: kuliah, ceramah, seminar.

b) Komunikasi kelompok besar (largegroupcommunication/publicspeaking). Yaitu komunikasi yang dilakukan dengan orang banyak atau ribuan orang dan dilakukan di tempat umum atau dilapangan. Masalnya : rapat raksasa. 
c) Komunikasi massa (masscommunication). Yang dimaksud komunikasi massa adalah komunikasi melalui media massa misalnya: surata kabar, majalah, radio, televisi, film. Komunikasi massa mempunyai bebera ciriciri diantaranya : [1] Komunikasi massa berlangsung satu arah. Pesan pada komunikasi massa melembaga, [2] komunikasi massa bersifat heterogen [3] pesan pada komunikasi massa bersifat umum (Onong Uchjana Effendy, 2001).

d] Komunikasi media (mediacommunication) merupakan segala sesuatu yang dapat diindra yang berfungsi sebagai perantara atau sarana untuk proses komunikasi. Agar komunikasi berjalan secara lancar dalam artian informasi dapat sampai secara tepat, cepat diperlukan media yang efektif pula. Komunikasi media dapat dikelompokkan sebagai berikut : [1] media auditif yakni informasi yang disalurkan melalui pendengaran, sehingga berbentuk komunikasi lisan seperti telepon. [2] media visual yakni informasi yang disalurkan melalui penglihatan, yang salah satu bentuknya berupa informasi tertulis yang disalurkan. Seperti surat, poster, spanduk. [3] media audio-visual yakni penyampaian informasi melalui pendengaran dan penglihatan sehingga berbentuk komunikasi lisan dan tertulis atau gambar (Hadari Nawawi, 1997).

\section{Fungsi komunikasi Guru}

Komunikasi guru di ruang publik sekolah dilakukan dengan beberapa fungsi:

1. Fungsi Komunikasi Sosial, Fungsi komunikasi sosial menunjukkan bahwa komunikasi penting untuk (Riswandi, 2009):

a. Membangun konsep diri

Konsep diri ialah pandangan kita tentang siapa diri kita yang diperoleh dari informasi yang diberikan orang lain kepada kita. Manusia yang tidak pernah berkomunikasi dengan manusia lainnya tidak mungkin mempunyai kesadaran bahwa dirinya adalah manusia. Kita sadar bahwa 
kita manusia, karena orang-orang disekeliling kita menunjukkan kepada kita lewat perilaku verbal dan nonverbal mereka bahwa kita manusia.

Aspek-aspek konsep diri seperti jenis kelamin, usia, agama, suku, pendidikan, bentuk muka, minat, dan sebagainya diinternalisasikan lewat pernyataan (umpan balik) orang lain yang menegaskan aspek-aspek tersebut kepada kita, dan pada gilirannya menuntut kita berperilaku sebagaimana orang lain memandang kita.

Menurut para ahli, konsep diri berupa identitas etnik merupakan unsur konsep diri yang penting, yang diartikan sebagai "perasaan kontinuitas dengan masa lalu, perasaan yang dipupuk sebagai bagian penting definisi diri". Dalam konteks ini, identitas etnik seseorang berkembang melalui internalisasi atas "kekuasaan" (typication) diri oleh orang lain, khususnya orang-orang dekat di sekitarnya, mengenai siapa orang itu dan siapa orang lain berdasarkan latar belakang etnik. Internalisasi simbol, tanda dan perilaku etnik ini terjadi tidak hanya pada masa kanak-kanak, namun juga dalam lingkungan yang lebih luas hingga tahap-tahap kehidupan selanjutnya.

Charles $\mathrm{H}$. Cooley menyebut konsep diri itu sebagai the looking glass-self yang secara signifikan ditentukan oleh apa yang seseorang pikirkan mengenai pikiran orang lain terhadapnya. Jadi, menekankan respon orang lain yang diinterpretasikan secara subjektif sebagai sumber primer data mengenai diri sendiri (Riswandi, 2009).

b. Eksistensi dan aktualisasi diri

Pernyataan eksistensi diri, orang berkomunikasi menunjukkan bahwa dirinya eksis. Ketika kita berbicara atau berkomunikasi dengan orang lain, baik verbal maupun non verbal, ini menunjukkan bahwa diri kita eksis atau ada. Dengan dasar ucapan filosof Perancis Rene Descartes mengatakan "Cogito Ergo Sum" (Saya berpikir, maka Saya ada), kita juga dapat mengatakan bahwa "Saya berbicara, maka Saya 
ada". Bila kita diam saja dalam suatu acara rapat atau seminar, maka orang lain akan memperlakukan kita seolah-olah tidak ada (Riswandi, 2009).

c. Kelangsungan hidup, memupuk hubungan dan mencapai kebahagiaan

Sejak manusia lahir, ia tidak dapat hidup sendiri untuk mempertahankan hidupnya. Manusia perlu dan harus berkomunikasi dengan orang lain untuk memenuhi kebutuhan hidupnya seperti makan, minum dan mencapai kebahagiaan.

Menurut para psikolog, kebutuhan utama kita sebagai manusia yang sehat secara rohaniah adalah kebutuhan akan hubungan sosial yang baik dengan orang lain. Abraham Maslow mengemukakan 5 kebutuhan dasar manusia yaitu kebutuhan fisiologis, keamanan, kebutuhan sosial, penghargaan diri dan kebutuhan aktualisasi diri (Riswandi, 2009).

Komunikasi sosial mengisyaratkan bahwa komunikasi dilakukan untuk pemenuhan diri, untuk menghibur diri, merasa nyaman dan tentram dengan diri sendiri dan orang lain. Penelitian para psikolog membuktikan bahwa banyak perilaku manusia dimotivasi oleh kebutuhan untuk menjaga keseimbangan emosional atau mengurangi ketegangan internal dan rasa frustasi. Itulah sebabnya bisa dipahami mengapa seseorang yang mengemukakan persoalan pribandinya kepada orang lain yang dipercayainya merasa beban emosionalnya menjadi berkurang. Komunikasi fatik semacam ini sekaligus dapat berfungsi sebagai mekanisme untuk menunjukkan ikatan sosial dengan orang yang bersangkutan.

2. Fungsi komunikasi ekspresif Erat kaitannya dengan komunikasi sosial adalah komunikasi ekspresif yang dapat dilakukan secara sendiri dan kelompok. Komunikasi ekspresif tidak otomatis bertujuan mempengaruhi orang lain, namun dapat dilakukan sejauh komunikasi tersebut menjadi 
instrumen untuk menyampaikan pesan-pesan non verbal misalnya, perasaan sayang, marah, benci, takut, sedih atau simpati, dapat dikomunikasikan melalui perilaku non verbal.

3. Fungsi komunikasi ritual Erat kaitannya dengan komunikasi ekspresif adalah komunikasi ritual, yang biasanya dilakukan secara kolektif. Suatu komunitas sering melakukan upacara-upacara berlainan sepanjang tahun dan sepanjang hidup, yang disebut para antropolog sebagai rites of passage, mulai dari upacara tujuh bulanan, kelahiran, sunatan, ulang tahun, pertunangan, pernikahan, naik haji ke Mekkah dan sebagainya.

Dalam upacara-upacara tersebut, orang-orang mengucapkan katakata atau menampilkan perilaku tertentu yang bersifat simbolik. Ritus-ritus lainnya adalah seperti sholat, upacar bendera, wisuda, natal dan lebaran. Mereka yang berpartisipasi dalam bentuk komunikasi ritual tersebut menegaskan kembali komitmen mereka kepada tradisi keluarga, suku, bangsa, negara, ideologi atau komitmen pada agama mereka.

Kegiatan ritual memungkinkan para pesertanya berbagi komitmen emosional dan menjadi perekat bagi kesatuan kelompok dan merupakan pengabdian bagi kelompok dimana individu tersebut menjadi anggotanya, yang menjadi perhatian dan hal yang terpenting bukanlah substansi kegiatan ritual itu sendiri, melainkan perasaan senasib sepenanggungan yang menyertainya, yaitu perasaan bahwa diri kita sendiri dan kita bersedia berkorban untuknya.

Komunikasi ritual ini bisa jadi akan tetap ada sepanjang zaman, karena ia merupakan kebutuhan manusia, meskipun bentuknya berubah-ubah demi pemenuhan kebutuhan dirinya sebagai makhluk individu, anggota komunitas tertentu, makhluk sosial dan sebagai salah satu bagian dari alam semesta.

4. Fungsi komunikasi instrumental Komunikasi instrumental mempunyai beberapa tujuan umum, yaitu (Riswandi, 2009): [a] menginformasikan, 
[b]Mengajar, [c] mendorong, [d] mengubah sikap, keyakinan dan perilaku, [e] menggerakkan tindakan, dan [f] menghibur.

Semua tujuan tersebut diatas dapat dikelompokkan membujuk atau bersifat persuasif. Komunikasi yang berfungsi memberitahukan atau menerangkan mengandung muatan persuasif dalam arti bahwa pembicara menginginkan pendengarnya mempercayai bahwa informasi yang disampaikannya akurat dan layak untuk diketahui.

Sebagai instrumen, komunikasi tidak saja digunakan untuk menciptakan dan membangun hubungan, akan tetapi juga sekaligus untuk merusak dan menghancurkan hubungan tersebut.

\section{Faktor-faktor komunikasi guru yang efektif}

Komunikasi yang dilakukan di ruang publik masih menggunakan teori klasik dari Wilbur Schramm mengemukakan apa yang disebut "the condition of success in communication" yakni kondisi yang harus dipenuhi jika menginginkan agar suatu pesan membangkitkan tanggapan yang kita kehendaki. Kondisi tersebut dapat dirumuskan sebagai berikut (Onong Uchjana Effendi, 2001):

1. Pesan harus dirancang dan disampaikan sedemikian rupa, sehingga dapat menarik perhatian komunikan.

2. Pesan harus menggunakan lambang-lambang tertuju kepada pengalaman yang sama antara komunikator dan komunikan, sehingga sama-sama mengerti.

3. Pesan harus membangkitkan kebutuhan pribadi komunikan dan menyarankan beberapa cara untuk memperoleh kebutuhan tersebut.

4. Pesan harus menyarankan suatu jalan untuk memperoleh kebutuhan tadi yang layak bagi situasi kelompok dimana komunikan berada pada saat ia digerakkan untuk memberikan tanggapan yang dikehendaki.

Adapun faktor-faktor yang terdapat pada komunikan dan komunikator, sebagai berikut (Onong Uchjana Effendi, 2001): 
1. Faktor pada komponen komunikan

Dengan memperhatikan syarat tersebut jelaslah, mengapa para ekspert komunikator memulai dengan meneliti sedalam-dalamnya tujuan komunikan dan mengapa "know your audience" merupakan ketentuan utama dalam komunikasi. Sebabnya ialah karena penting sekali mengetahui: [1[ Waktu yang tepat untuk suatu pesan, [2] Bahasa yang harus dipergunakan agar pesan dapat dimengerti, [3] Sikap dan nilai yang harus ditampilkan agar efektif, [4] Jenis kelompok dimana komunikasi akan dilaksanakan.

Ditinjau dari komponen komunikan, seorang dapat dan akan menerima sebuah pesan hanya kalau terdapat empat kondisi berikut ini secara simultan: [1[ la dapat dan benar-benar mengerti pesan komunikasi, [2] Pada saat ia mengambil keputusan, ia sadar bahwa keputusannya itu sesuai dengan tujuannya, [3] Pada saat ia mengambil keputusan, ia sadar bahwa keputusan itu bersangkutan dengan kepentingan pribadinya. [4] la mampu untuk menepatinya baik secara mental maupun secara fisik.

Demikian kata Chester I. Barnard. Dalam pada itu Cultip dan Center dalam bukunya "Effective Public Relations", mengemukakan fakta fundamental yang perlu diingat oleh komunikator, diantaranya (Onong Uchjana Effendi, 2001):

a. Bahwa komunikan terdiri dari orang-orang yang hidup, bekerja dan bermain satu sama lainnya dalam jaringan lembaga sosial. Karena itu, setiap orang adalah subjek bagi berbagai pengaruh, diantaranya adalah pengaruh dari komunikator.

b. Bahwa komunikan pembaca, mendengarkan dan menonton komunikasi yang menyajikan pandangan hubungan pribadi yang mendalam. 
c. Bahwa tanggapan yang diinginkan komunikator dari komunikan harus menguntungkan bagi komunikan, kalau tidak ia tidak akan memberikan tanggapan.

2. Faktor pada komponen komunikator

Ketika komunikator berkomunikasi, yang berpengaruh bukan saja apa yang ia katakan, tetapi juga keadaan dia sendiri. He doesn't communicate what he says, he communicates what he is. Artinya, ia tidak dapat menyuruh pendengar hanya memperhatikan apa yang ia katakan. Pendengar juga akan memperhatikan siapa yang mengatakan. Bahkan kadang-kadang unsur "siapa" ini lebih penting dari unsur "apa" (Onong Uchjana Effendi, 2001).

\section{Hambatan pola komunikasi guru}

Tidaklah mudah untuk melakukan komunikasi secara efektif. Bahkan beberapa ahli komunikasi menyatakan bahwa tidak mungkinlah seseorang melakukan komunikasi yang sebenar-benarnya efektif. Ada banyak hambatan yang bias merusak komunikasi. Berikut ini adalah beberapa hal yang merupakan hambatan komunikasi yang harus menjadi perhatian bagi komunikator kalau ingin komunikasinya sukses (Onong Uchjana Effendi, 2001).

Pada umumnya, sebuah komunikasi di kontrol oleh komunikator. Apabila seorang guru sedang mengajar di sebuah kelas, maka ia yang menentukan apa yang harus atau tidak harus disampaikan. Sepanjang dia mampu berkomunikasi dan dapat tampil dengan baik, maka pesan atau informasi yang disampaikannya akan diterima dengan baik pula oleh komunikatornya.

Adapun hambatan-hambatan komunikasi adalah, sebagai berikut Onong (Uchjana Effendi, 2001):

1. Gangguan 
Ada dua jenis gangguan terhadap jalannya komunikasi yang menurut sifatnya dapat diklasifikasikan sebagai gangguan mekanik dan gangguan semantik.

a. Gangguan mekanik (mechanical, channel noise) Yang dimaksudkan dengan gangguan mekanik ialah gangguan yang disebabkan saluran komunikasi atau kegaduhan yang bersifat fisik.

2. Gangguan semantik (semantic noise) Gangguan jenis ini bersangkutan dengan pesan komunikasi yang pengertiannya menjadi rusak. Gangguan semantik tersaring ke dalam pesan melalui penggunaan bahasa. Lebih banyak kekacauan mengenai pengertian suatu istilah atau konsep yang terdapat pada komunikator, akan lebih banyak gangguan semantik dalam pesannya. Gangguan semantik terjadi dalam salah pengertian.

Semantik adalah pengetahuan mengenai pengertian kata-kata yang sebenarnya atau perubahan pengertian kata-kata. Lambang kata yang sama mempunyai pengertian yang berbeda untuk orang-orang yang berlainan. Ini disebabkan dua jenis pengertian mengenai kata-kata: ada yang mempunyai pengertian denotatif dan ada yang mempunyai pengertian konotatif.

Pengertian denotatif (denotative meaning) adalah pengertian suatu perkataan yang lazim terdapat dalam kamus yang secara umum diterima oleh orang-orang dengan bahasa dan kebudayaan yang sama. Sedangkan, pengertian konotatif (conotative meaning) adalah pengertian yang bersifat emosional latar belakang dan pengalaman seseorang.

a. Kepentingan Interest atau kepentingan akan membuat seseorang selektif dalam menanggapi atau menghayati suatu pesan. Orang akan hanya memperhatikan perangsang yang ada hubungannya dengan kepentingannya. Setiap peraturan yang dikeluarkan, apakah itu mengenai perburuhan, perkawinan, kurikulum baru dan sebagainya, ada saja yang merasa dirugikan. Pihak yang berkepentingan biasanya tidak 
mengajukan tanggapan dengan alasan yang sungguh-sungguh, tetapi seringkali mengetengahkan argumentasi dan alasan tersembunyi (disguised argumentation and reasons).

b. Motivasi terpendam, Motivasi akan mendorong seseorang berbuat sesuatu yang sesuai benar dengan keinginan, kebutuhan dan kekurangannya. Keinginan, kebutuhan dan kekurangan seseorang berbeda dengan orang lainnya, dari waktu ke waktu dan dari tempat ke tempat, sehingga karenanya motivasi itu berbeda dengan intensitasnya. Demikianlah intensitas tanggapan seseorang terhadap suatu komunikasi.

Semakin sesuai komunikasi dengan motivasi seseorang, semakin besar kemungkinan komunikasi itu dapat diterima dengan baik oleh pihak yang bersangkutan. Sebaliknya, komunikan akan mengabaikan suatu komunikasi yang tak sesuai dengan motivasinya. Sehingga, seringkali pula terjadi seorang komunikator tertipu oleh tanggapannya komunikan yang seolah-olah tampaknya khusu (attentive) menanggapinya, sungguh pun pesan komunikasi tak bersesuaian dengan motivasinya. Tanggapan semu dari komunikan itu tentunya mempunyai motivasi terpendam.

c. Prasangka prejudice atau prasangka merupakan salah satu rintangan atau hambatan berat bagi suatu kegiatan komunikasi, oleh karena itu orang yang mempunyai prasangka belum apa-apa sudah bersikap curiga dan menentang komunikator yang hendak melancarkan komunikasi. Dalam prasangka, emosi memaksa kita untuk menarik kesimpulan atas dasar syak wasangka tanpa menggunakan pikiran yang rasional. Emosi seringkali membutakan pikiran dan pandangan kita terhadap fakta yang nyata. Sekali rasangka itu sudah mencekam, maka seseorang tak akan dapat berpikir secara objektif dan segala apa yang dilihatnya selalu akan dinilai secara negatif. Sesuatu yang objektif pun akan dinilai negatif. 
Prasangka bukan saja dapat terjadi terhadap suatu ras, melainkan juga terhadap agama, pendirian politik, kelompok, atau suatu perangsang yang dalam pengalaman pernah memberi kesan yang tidak enak.

\section{KESIMPULAN}

Kesimpulan yang dapat diambil dalam penelitian ini, menunjukan bahwa pola komunkasi guru di ruang publik sekolah telah berlangsung secara efektif dan intens melalui: [1] proses komunikasi guru yang dilakukan melalui pengamatan prilaku peserta didik untuk mengetahui seluk beluk psikologi setiap peserta didik. Kemudian guru berusaha membangun komunikasi yang baik dengan tujuan menarik simpati. Hal ini dilakukan karena nampak beberapa peserta didik yang kurang bersemangat dalam proses pembelajaran, seperti: tidak fokus dalam belajar, tidak bisa menghafal di depan kelas, dan kurang memperhatikan tugas sekolah. [2] Pola komunikasi guru yang digunakan dalam pembelajaran yaitu: Pola komunikasi personal dan kelompok meliputi; [a] komunikasi verbal seperti, menyampaikan materi secara langsung kepada peserta didik. [b] nonverbal, seperti: menunjukkan perilaku, gaya berpakaian yang rapi, gaya bicara dan cara dialog dengan guru ketika memberikan materi. [3] komunikasi bermedia seperti: menggunakan bukubuku yang berhubungan dengan materi yang diajarkan. Dengan pola komunikasi guru ini memberikan dampak yang positif terhadap peserta didik sehingga mereka dapat termotivasi untuk mengikuti materi pelajaran.

\section{DAFTAR PUSTAKA}

[1] Ali, Mohammad. 1993. Strategi Penelitian Pendidikan. Bandung: Angkasa.

[2] Brophy, J. 2004. Reliabilitas Dan Validitas. Yogyakarta: Pustaka Pelajar.

[3] , Onong Uchjana. 1993. IImu, Teori \& Filsafat Komunikasi. Bandung: Citra Aditya Bakti. 
[4] Juliana. Sistem Komunikasi dan Cara Bicara Antara Guru dan Murid.Http://Sistem Komunikasi dan Cara Bicara Antara Guru dan Murid - KOMPASIANA.com.html//. Diakses pada Kamis, 24 Maret 2016.

[5] Nawawi, Hadari. 1997. Adminsitrasi Pendidikan. Jakarta: Toko Gunung Agung.

[6] Onong Uchjana. 2001. Ilmu Komunikasi; Teori dan Praktik. Bandung: Remaja Rosdakarya.

[7] Riswandi,. 2009. Ilmu Komunikasi. Yogyakarta: Graha IImu.

[8] Sanjaya, Wina. 2006. Strategi Pembelajaran. Jakarta: Prenademedia Group.

[9] Syah, Muhibin. 1995. Psikologi Pendidikan. Bandung: Remaja Rosdakarya.

[10] Uno, Hamza. 2007. Profesi Kependidikan. Jakarta: Bumi Aksara.

[11] Yusuf, Pawit M. 1990. Komunikasi Pendidikan Dan Komunikasi Instruksional. Bandung: Remaja Rosda Karya. 